\title{
Perancangan Game Edukasi Menyusun Ayat Al-Qur'an Berbasis Android
}

\author{
Sari Setyaning Tyas ${ }^{1}$, Romeizatul Huwaida $^{2}$, Yudha Pradana ${ }^{3}$ \\ ${ }^{1}$ Teknologi Rekayasa Multimedia \\ ${ }^{2}$ Teknologi Rekayasa Multimedia \\ Email: ${ }^{1}$ sarist@ polimedia.ac.id, ${ }^{2}$ meiza.lavigne@gmail.com \\ Email: 1yudha.pradana@polimedia.ac.id
}

\begin{tabular}{l} 
INFORMASI ARTIKEL \\
\hline Sejarah Artikel: \\
Diterima Redaksi:20 November 2020 \\
Revisi Akhir: 1 Desember 2020 \\
Diterbitkan Online: 15 Desember 2020 \\
KATA KUNCI
\end{tabular}

Game Edukasi

Aplikasi Android

Pengenalan Alquran

\begin{tabular}{l} 
KORESPONDENSI \\
\hline Yudha Pradana, M.Pd \\
Program Studi Teknologi Rekayasa \\
Multimedia \\
Politeknik Negeri Media Kreatif
\end{tabular}

Email: ${ }^{1}$ yudha.pradana@polimedia.ac.id

\section{A B S T R A C T}

Sekolah Dasar Avicenna Jagakarsa menerapkan sistem pembelajaran yang mewajibkan murid untuk menghafal surat-surat pendek dalam mata pelajaran Pendidikan Agama Islam (PAI). Sebagai solusinya dibuat Game edukasi yang merupakan salah satu sarana media pembelajaran untuk dapat meningkatkan minat siswa belajar aktif dan kreatif, sehingga belajar menjadi terasa menyenangkan. Game edukasi ini bernama "Menyusun Ayat Alquran". Game berbasis Android dengan materi soal-soal yang ditampilkan secara acak dan berasal dari buku-buku pelajaran PAI kelas 1 sampai 5 yang digunakan SD Avicenna Jagakarsa.

\begin{abstract}
Avicenna Jagakarsa Elementary School implements a learning system that requires students to memorize surah in islamic Religious Education. As a solution, an educational game was made which is a means of learning media to be able to increase students interest in active and creative learning, so that learning becomes fun. This educational game is called "Menyusun Ayat Alquran" game based on Android with question material displayed randomly from textbooks and comes from PAI class 1 to 5 used by SD Avicenna Jagakarsa
\end{abstract}

\section{PENDAhUluAN}

Alquran merupakan kitab suci umat Islam yang menjadi pedoman kehidupan sehari-hari. Umumnya, orang tua sudah memperkenalkan Alquran pada anak sejak usia dini. Masa kanak-kanak adalah masa yang paling tepat untuk memulai menghafal Alquran. Arinal (2017) menyebutkan bahwa anak memiliki kemampuan akal yang putih bersih yang tidak dipenuhi oleh kesibukan dan pikiran seperti orang dewasa. Karenanya, beberapa orang tua memilih untuk menyekolahkan anaknya di lembaga pendidikan berbasis agama Islam yang memiliki program hafalan Alquran sejak dini, seperti yang diterapkan di SD Avicenna Jagakarsa.

Sekolah ini menerapkan sistem pembelajaran kurikulum 2013 (K13). Berdasarkan lampiran permendikbud tahun 2016 disebutkan bahwa dalam Kompetensi Inti (KI) dan Kompetensi Dasar (KD) Pendidikan Agama Islam Dan Budi Pekerti SD/MI pada Lampiran Permendikbud RI No. 024 Tahun 2016, murid diajarkan untuk melafalkan, menghafalkan, dan mengimplementasikan pemahaman tentang surat-surat pendek. Selain dikarenakan penerapan K13, SD Avicenna Jagakarsa memiliki kurikulum tersendiri untuk meningkatkan kemampuan murid dalam membaca dan menghafal Alquran. Sekolah ini memiliki program tambahan untuk pembelajaran Alquran secara intensif, yaitu dengan membuat mata pelajaran muatan lokal BTQ (Baca Tulis Quran). Selain itu, salah satu program pembelajaran yang diterapkan SD Avicenna Jagakarsa adalah pembelajaran dengan multimedia, seperti presentasi menggunakan PowerPoint dan kegiatan audiovisual. Namun, hal tersebut masih belum diterapkan dalam sistem pembelajaran hafalan Alquran dalam mata pelajaran Pendidikan Agama Islam (PAI), pembelajaran masih menggunakan metode yang konvensional. Atas dasar hal tersebut, dibutuhkan sebuah media pembelajaran interaktif bagi murid untuk menghafal Alquran, terutama surat-surat pendek yang dipelajari.

Teknologi saat ini dianggap dapat mampu membantu meningkatkan efektifitas dunia pendidikan karena semuanya serba digital, salah satunya dapat kita 
manfaatkan perangkat handphone android. Dwiyono (2017) menyebutkan bahwa perpaduan dunia teknologi dan pendidikan mampu memberikan inovasi baru pada proses pembelajaran, seperti melalui pengembangan game edukasi. Game merupakan salah satu fitur yang cepat dipahami oleh anak-anak. Sebagian besar anak-anak juga lebih senang dan cepat dalam belajar menghafal lagu anakanak, menghafal bacaan Alquran, belajar membaca, mengenal warna, mengenal bentuk dan benda, serta belajar berhitung dengan menggunakan gawai (gadget). Game memberikan kenyamanan dan kefokusan anak untuk memainkannya dengan mudah. Game edukasi dapat mendorong peserta didik untuk belajar aktif dan kreatif serta lebih memahami akan materi yang diberikan melalui aplikasi yang dapat diakses kapan saja.

\section{METODE PENELITIAN}

Metodologi yang digunakan pada penelitian ini adalah menggunakan IMSDD (Interactive Multimedia System Design and Development Cycle), urutan pengerjaan IMSDD diantarannya

a. Analisa Kebutuhan Sistem, yaitu melakukan pendefinisian sistem, profil pengguna sistem, perangkat keras dan perangkat lunak yang dibutuhkan, serta pendistribusian sistem

b. Desain, diantarannya metafora desain, format dan tipe file, serta navigasi

c. Implementasi, yaitu melakukan pembuatan antarmuka interaktif, dan

d. Evaluasi, melakukan peninjauan dari aspek IMK (Interaksi Manusia dan Komputer)

\section{PERANCANGAN SISTEM}

Menggunakan flowchart dalam melakukan perancangan sistem pada aplikasi Menyusun Ayat Alquran

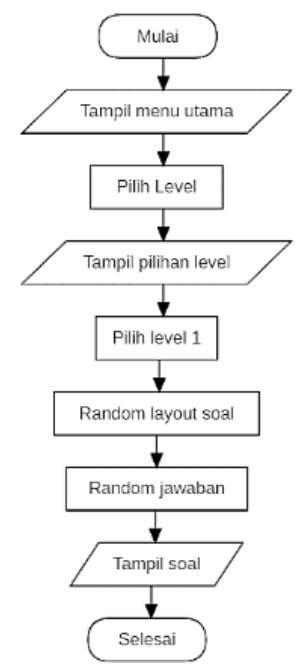

Gambar 1.Flowchart Acak Soal

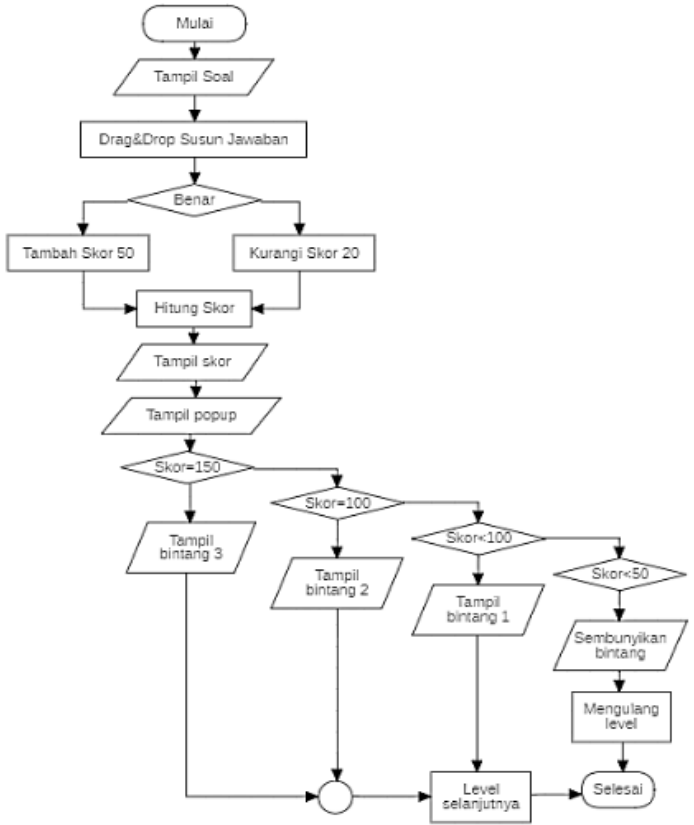

Gambar 2.Flowchart Skor

\section{HASIL DAN PEMBAHASAN}

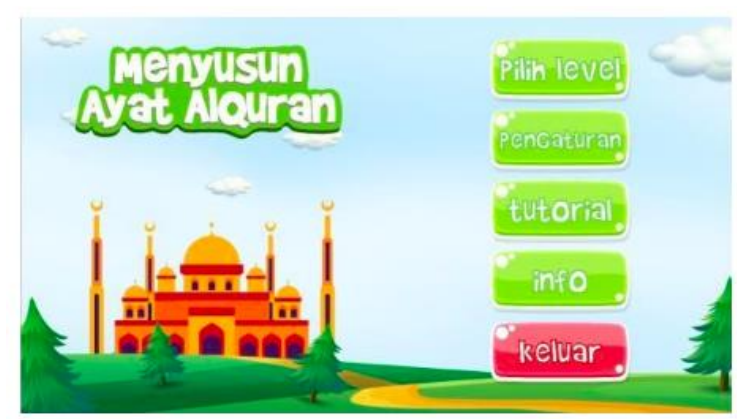

Gambar 3. Halaman Utama

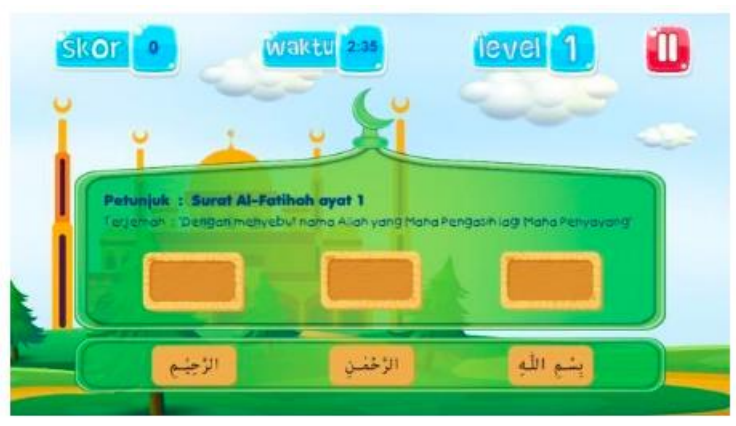

Gambar 4. Level 1

Tabel 1. Uji Aplikasi

\begin{tabular}{|l|l|l|}
\hline Perangkat & Respon Klik Aplikasi & $\begin{array}{l}\text { Respon Game } \\
\text { drag\&drop }\end{array}$ \\
\hline 1 & Responsif (1detik) & $\begin{array}{l}\text { Responsif } \\
\text { (1detik) }\end{array}$ \\
\hline 2 & Responsif (1detik) & $\begin{array}{l}\text { Responsif } \\
\text { (2 detik) }\end{array}$ \\
\hline 3 & Responsif (2detik) & $\begin{array}{l}\text { Responsif } \\
\text { (3detik) }\end{array}$ \\
\hline
\end{tabular}


Berdasarkan hasil uji coba aplikasi Menyusun Ayat Alquran yang dilakukan pada perangkat smartphone dapat disimpulkan bahwa aplikasi Menyusun Ayat Alquran berjalan sangat baik pada OS android versi 8.0 (oreo) dengan prosesor Octa-core 2,45 GHz. Kecepatan rata-rata respon sistem adalah 1 detik.

\section{KESIMPULAN}

Pembuatan game edukasi Menyusun Ayat Alquran merupakan media pembelajaran yang dapat dijadikan sebagai alternatif alat belajar yang dapat diakses kapan saja serta membantu peserta didik di SD Avicenna Jagakarsa untuk menghapal surat-surat pendek. Aplikasi menyusun Ayat Alquran sangat baik berjalan pada OS android versi 8.0 (oreo) dengan prosesor Octa-core 2,45 GHz. Kecepatan rata-rata respon sistem adalah 1 detik

\section{DAFTAR PUSTAKA}

Dwiyono. (2017). Pengembangan Game Edukasi Sebagai Media Pembelajaran Interaktif Pada Kompetensi Dasar Mendeskripsikan Penggunaan Peralatan Tangan (Hand Tools) Dan Peralatan Bertenaga (Power Tools). Yogyakarta: Universitas Negeri Yogyakarta.

Hansun, S. et al. (2018). Pemrograman Android Studio IDE. Yogyakarta: Penerbit ANDI.

Haq, H. A. (2017). Peran Orang Tua Terhadap Anak Dalam Menghafal Alqur'an Di Taman Pendidikan Tahfidz Alqur'an Darussunnah Banaran Sragen. Surakarta: Institut Agama Islam Negeri Surakarta.

Islamiyati, R. A. (2017). Pemanfaatan Handphone dalam Proses Pembelajaran Ekonomi Di SMA A dan SMA B Jakarta Selatan. Jakarta: Universitas Islam Negeri Syarif Hidayatullah.

Jubilee Enterprise. (2015). Mengenal Dasar-dasar MenuPemrograman Android. Jakarta: PT Elex Media Komputindo.

Mendikbud RI. (2016). Lampiran Permendikbud RI No.024 Tahun 2016. Jakarta: Kementrian Pendidikan dan Kebudayaan Republik Indonesia.

Pane, B. et al. (2017). E-Journal Teknik Informatika. Rancang Bangun Aplikasi Game Edukasi Ragam Budaya Indonesia, Vol. 2 No.1. 